Nova Biologica Reperta 6(4): 415-423 (2020)

Print ISSN: 2423-6330/Online ISSN: 2476-7115

https://nbr.khu.ac.ir; Kharazmi University Press; DOI: 10.29252/nbr.6.4.415
يافتهاى نوين در علوم زيستى

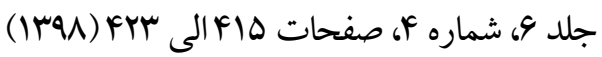

$$
\text { انتشارات دانشخاه خوارزمى }
$$

$$
\begin{aligned}
& \text { بررسى روش هاى غربالَّى و :بروفايل آنزيمى باكترىهاى اندوفيت گَياهان زراعى }
\end{aligned}
$$

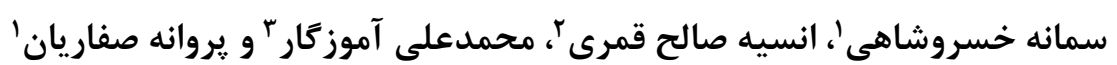

$$
\begin{aligned}
& \text { اگروه زيست شناسى، دانشكده علوم يايه، واحد علوم و تحقيقات، دانشگاه آزاد اسلامى، تهران، ايران؛ זَّروه علوم سلولى و مولكولى، دانشكده علوم زيستى، دانشعاه }
\end{aligned}
$$

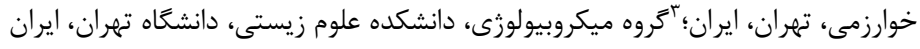

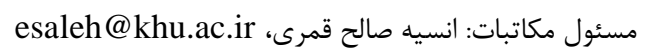

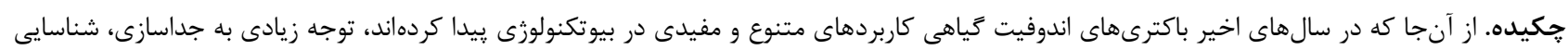

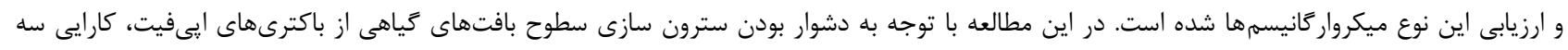

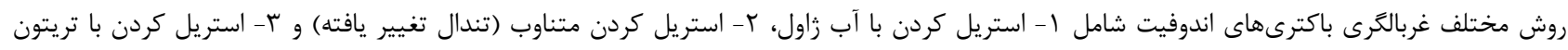

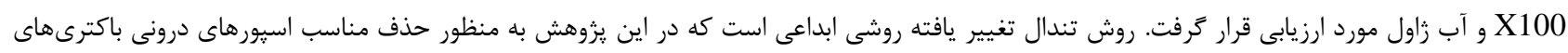

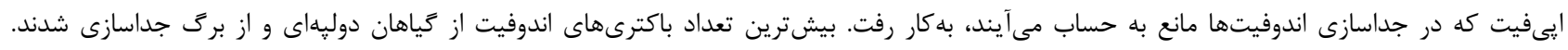

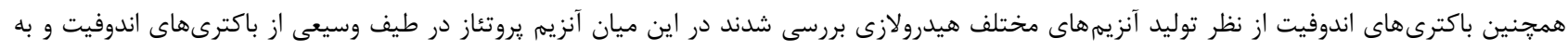

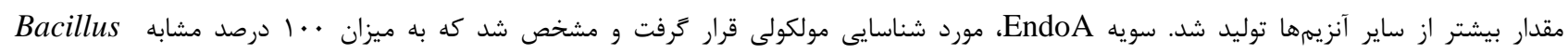
halotolerans

وازمهاى كليدى. آنزيمهاى هيدرولازى، باسيلوس هالوتولرانس، بروتئاز، زايلاناز، كيتيناز

\title{
Screening methods and enzyme profile of agricultural plant-endophytic bacteria
}

\section{Samaneh Khosroshahi' ${ }^{1}$ Ensieh Salehghamari², Mohammad Ali Amoozegar ${ }^{3}$ \& Parvaneh $^{2}$ Saffarian $^{1}$}

${ }^{1}$ Department of Biology, Faculty of Basic Science, Islamic Azad University, Tehran, Iran; ${ }^{2}$ Department of Cell and Molecular Sciences, Faculty of Biological Sciences, Kharazmi University, Tehran, Iran; ${ }^{3}$ Department of Microbiology, School of Biology, University College of Science, University of Tehran, Tehran, Iran

Correspondent author: Ensieh Salehghamari, esaleh@khu.ac.ir

\begin{abstract}
Nowadays plant endophytic bacteria have found diverse and useful applications in biotechnology; therefore, much attention has been paid to the isolation, identification, and evaluation of these microorganisms. Since the sterilizing plant tissue surfaces from epiphytic bacteria is difficulty, the efficacy of three different screening methods for endophytic bacteria including 1- HClO sterilization, 2- Periodic sterilization (modified tyndallization) and 3- Triton $\mathrm{X} 100$ and $\mathrm{HClO}$ sterilization, was evaluated in this study. The modified Tyndallization is an innovative method used in this study to appropriately remove the internal spores of epiphytic bacteria, considered to be an obstacle to the isolation of endophytes. Most of the endophytic bacteria were isolated from dicotyledons and leaves. Endophytic bacteria were also studied for the production of different hydrolase enzymes, whereas the protease enzyme was produced in a wide range of endophytic bacteria in greater quantities than other enzymes. The EndoA strain was molecularly identified and found to be $100 \%$ similar to Bacillus halotolerans.
\end{abstract}

Key words. Bacillus halotolerans, chitinase, hydrolytic enzymes, protease, xylanas

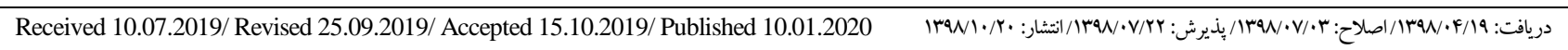




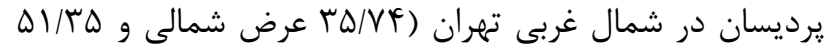
طول شرقى) جمع آورى شدند. روشهاى جداسازى باكترى إى إى اندوفيت

از تمامى قسمتهاى كياهان مذكور (برك، ريشه، ساقه و ميوه) نمونه بردارى صورت گرفت. براى حذف كرد و غبار و و همجنينين

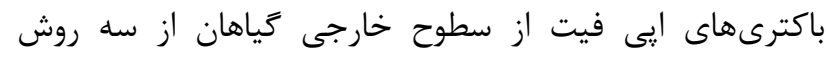

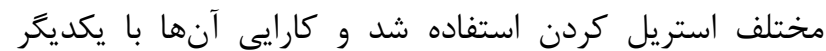

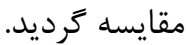
روش اول: نمونههاى كياهى به آرامى و با آب در حال جرئ جريان

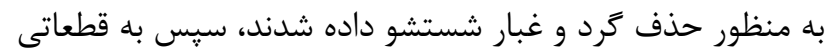

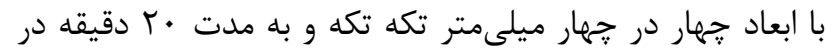

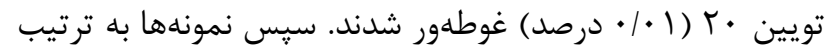

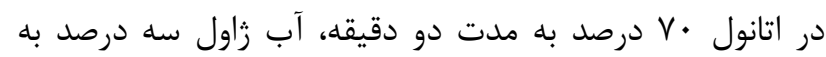
مدت سه دقيقه و اتانول • V درصد به مدت سه دقيقه غوطهور شدند و با آب مقطر استريل سه بار شستشو داده شدند. نمونهها

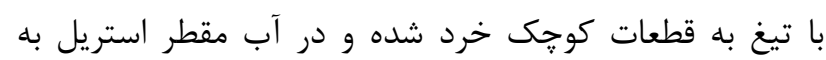

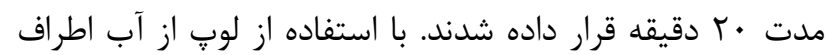
بافت برداشته و روى محيط كشت نوترينت آكار كشت داده شد.

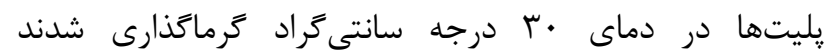

.(Teachowison et al., 2003)

روش دوم: نمونهاى گياهى به شش قطعه تقسيم شده و به

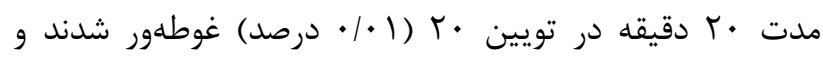

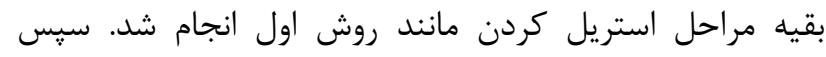

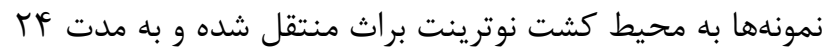

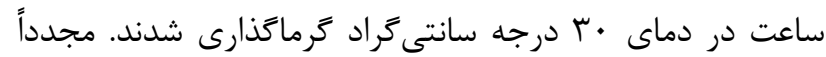

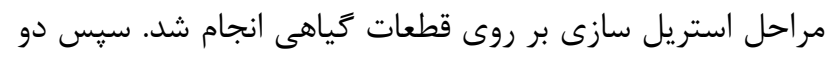
قطعه از اين قطعات بر روى محيط كشت نوترينت آكار قرار داده دادي

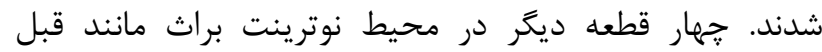
كرماكذارى شدند. سيس مراحل شستشو براى قطعات كياهى كه

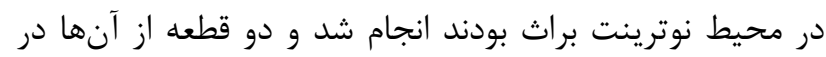

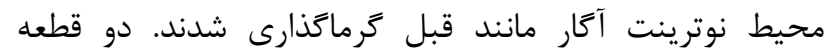
باقيمانده MF ساعت ديخر در محيط نوتريت براث گرماكذارى

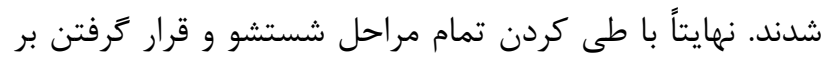

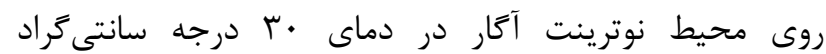

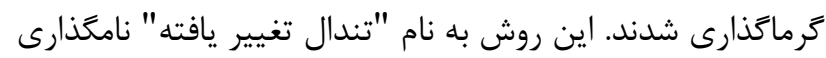

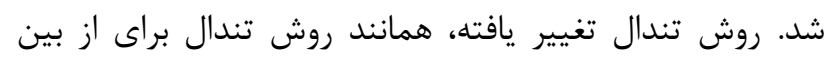

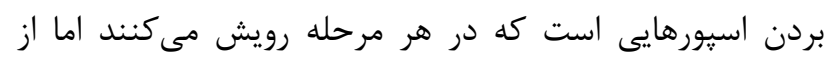

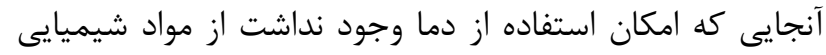

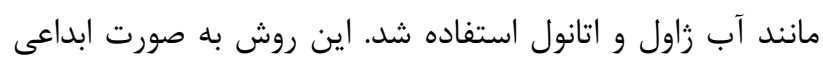
است و براى اولين بار در اين يزوهش به كار النفاده رفته است.
مقلهمه

باكترىهاى اندوفيت، ميكرواركانيسمهاى ويزهاى هستند كه

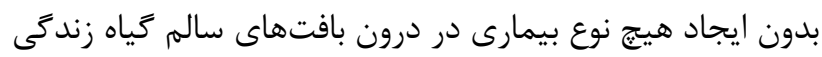

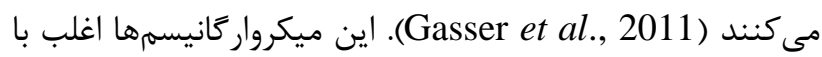

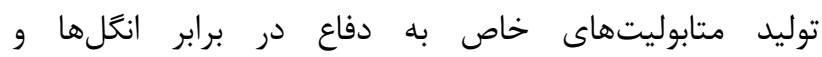
ميكروار كانيسمهاى بيماريزاى كياهى و همجنين بقاى مياى ميزبان كمك مى كنند (Sanchez-Lopez, et al., 2018). اين مين بين ميكرواركانيسهمها كه به صورت يك جامعنه ميكروبى هستند در

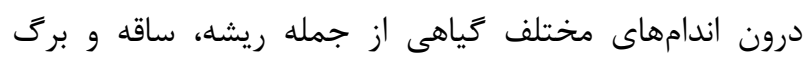

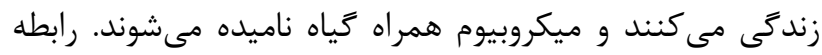

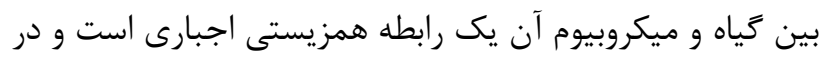

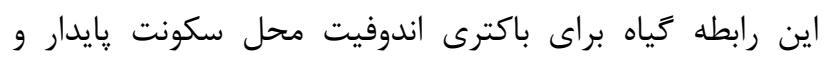

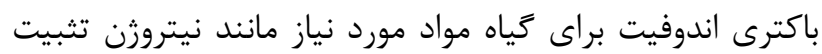

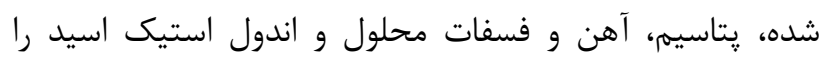

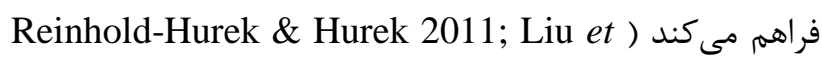
.(al., 2017

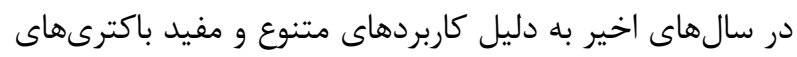

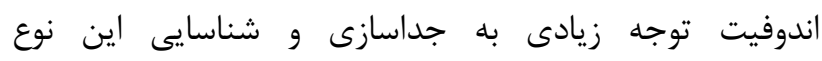

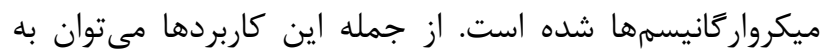

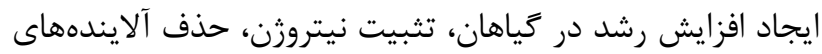

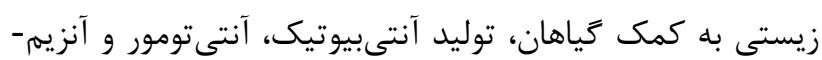

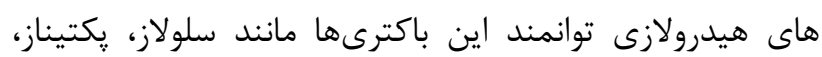
كيتيناز، آميلاز، يروتئاز و ليياز اشاره نمود ( Lodewyckx et (al., 2002; Christina et al., 2013

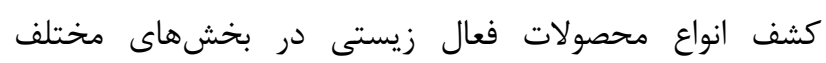

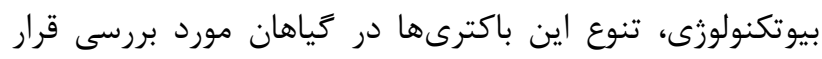

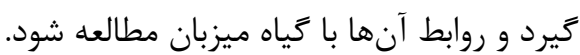

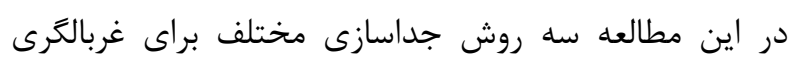

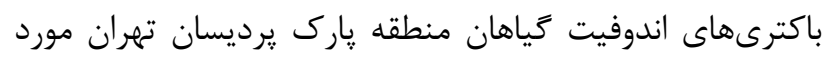

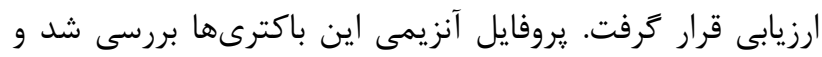

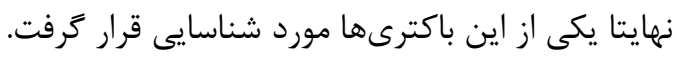

$$
\text { مواد و روش ها }
$$

\section{جمع آورى مواد كياهى}

نمونههاى كياهى شامل كوجه فرنكى، جو، كَندم، تره، توت، بنجامين، يونجه، عشقه، تاج خروس، هويج، كل جعفرى و انار به به

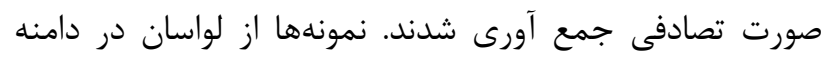

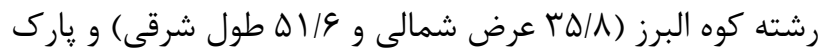


بر روى آن ريخته شد. ايجاد هاله شفاف اطراف كلنى نشان

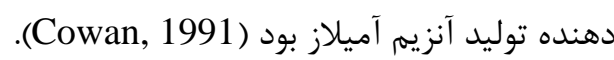

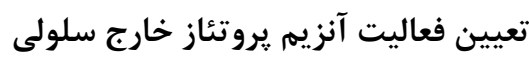

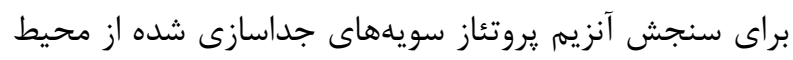

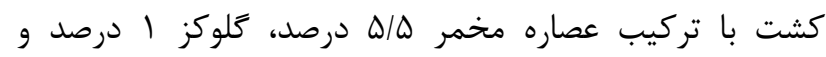

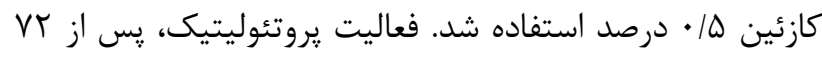

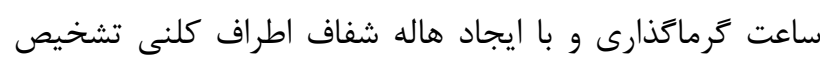

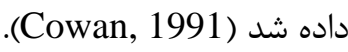

\section{تعيين فعاليت آنزيم كيتيناز خارج سلولى آلى آني}

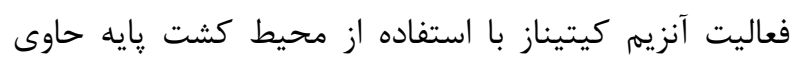

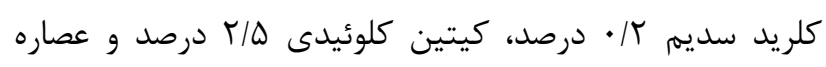

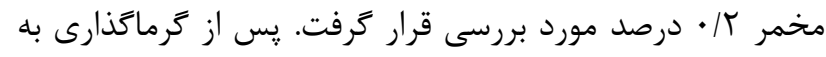

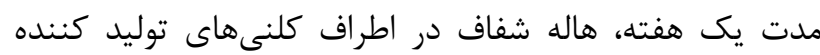
آنزيم كيتيناز مشاهده شد (Carrim et al., 2006).

\section{تعيين فعاليت آنزيم زايلاناز خارج سلولينى}

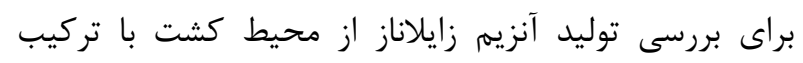

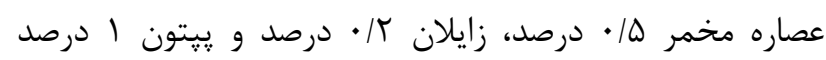

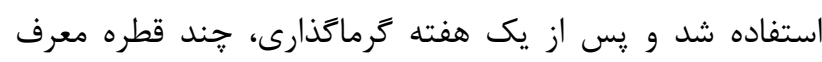

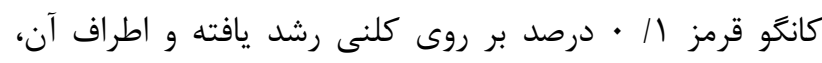

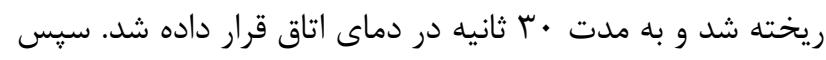

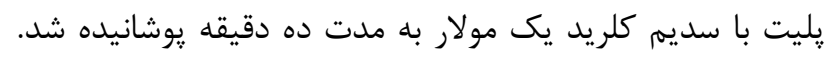

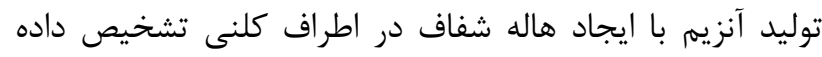

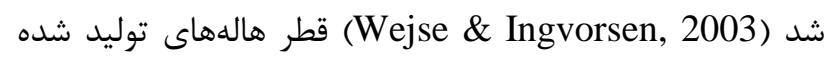
در اثر فعاليت آنزيمى توسط خط كش اندازه كيرى شد. شناسايى مولكولى باكترى اندوفيت انتخاب شده به روش ترئ تكثير رن 16S rDNA و بررسى روابط فيلوزنتيكى آن آن

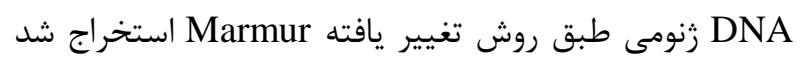
TE Marmur, 1961)

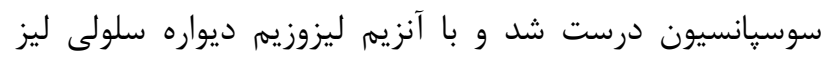

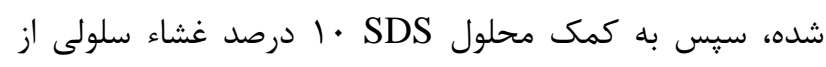

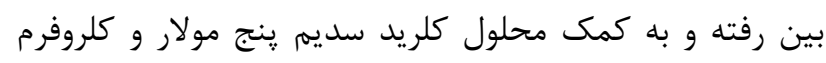

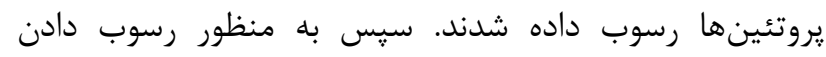

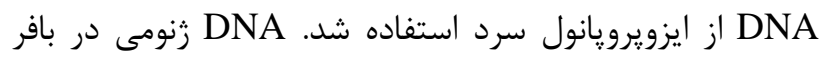
به به صورت محلول نكمهارى شد.

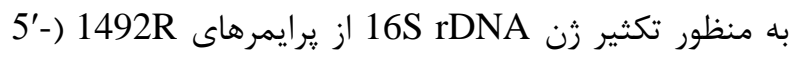
5'- ) 27F , (GGTTACCTTGTTACGACTT-3' و A AGAGTTTGATCMTGGCTCAG-3' يا C است.) استفاده شد (Kim et al., 2011). واكنش PCR

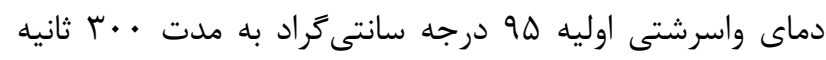

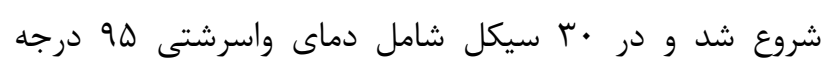

روش سوم: نمونهاى كياهى به قطعات كوجى برش داده

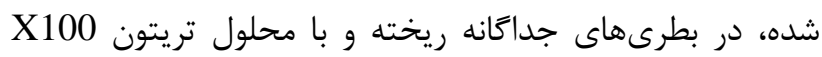

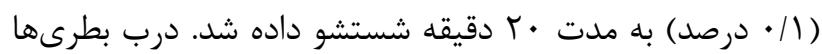

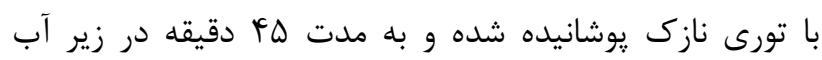

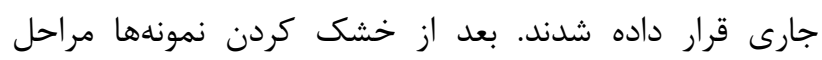

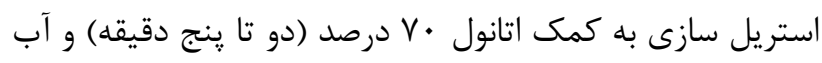

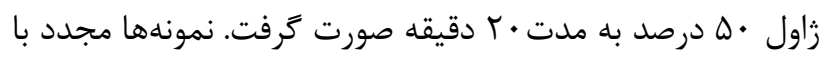

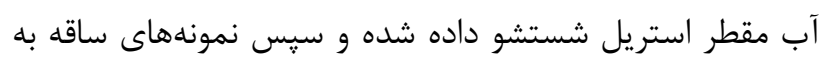

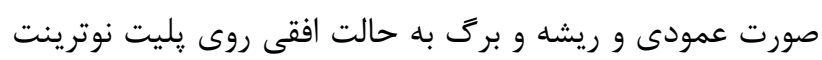

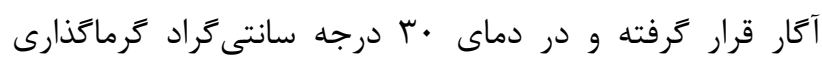
شدند (Reece et al., 2014).

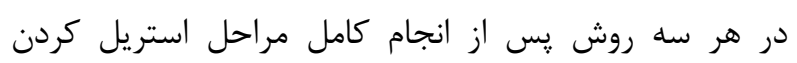

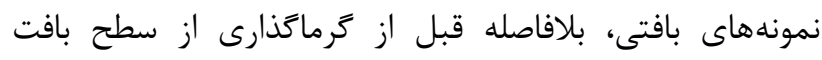

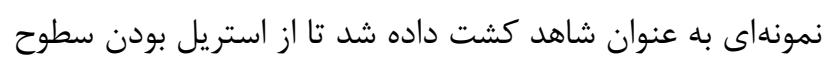
بافتها اطمينان حاصل شود. در هر سه روش به منظور جان جداسازى و نتحهدارى سويهها از

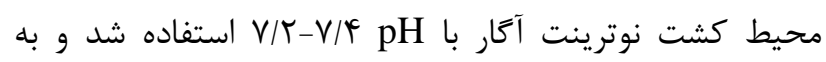
منظور مهار رشد قارجها در مراحل جداسازى باكت باكترىهاى

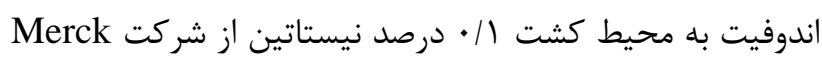

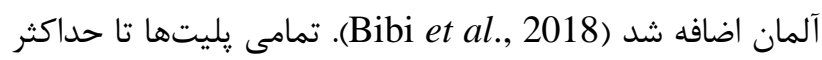

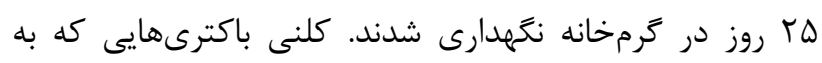

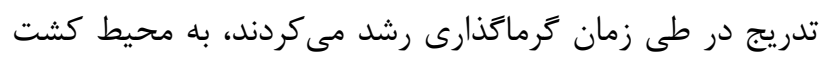

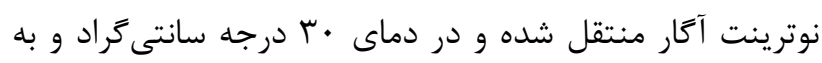

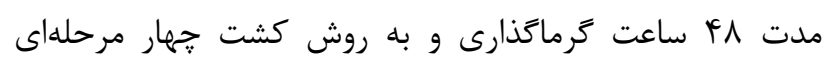

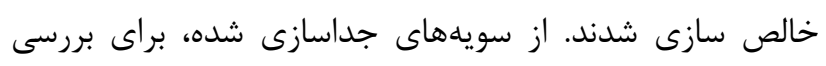

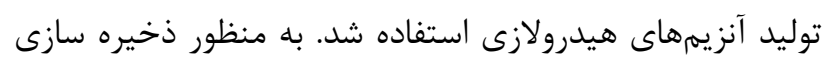

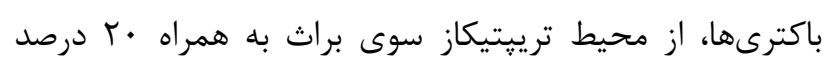

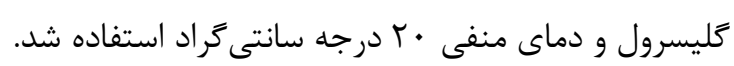

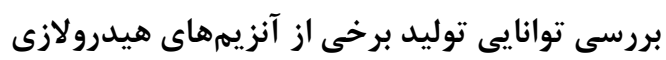

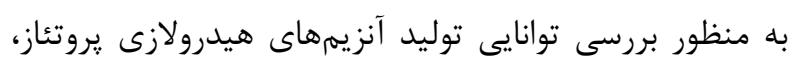

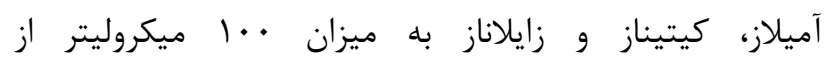

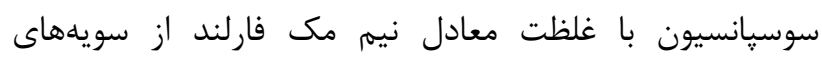

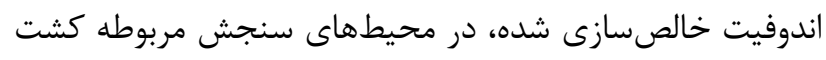

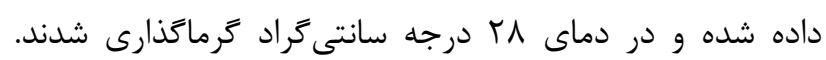

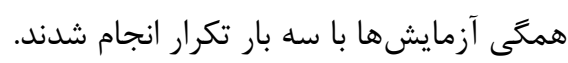

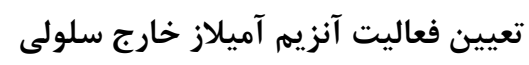

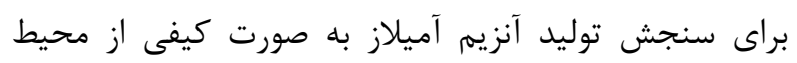

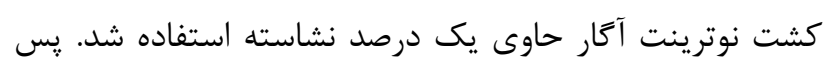

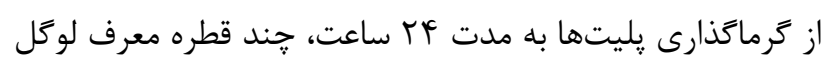


قطر هالهها به كمك خط كش اندازهگيرى شد. همجنين در بين آنزيمهاى مورد بررسى بالاترين ميزان توليد (قطر هاله دو

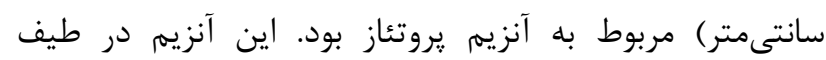

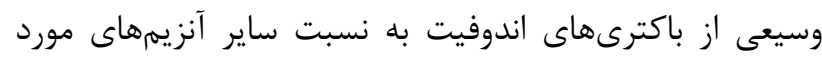
مطالعه توليد شد و قطر هاله توليد شده توسط آنزيم مذكور در اغلب سويههاى اندوفيتى مورد مطالعه دو سانتىمتر بود (شكل ه). قطر هاله توليد شده توسط آنزيم زايلاناز در سويههاى توليد

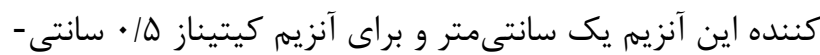
متر اندازه كيرى شد.

در بين باكترىهاى اندوفيت جداسازى شده سويهها، توليد كننده دو نوع از آنزيمهاى مورد بررسى بودند بدين صورت كه تعداد א/N ترتيب توليد كننده "يروتئاز و زايلاناز"، "يروتئاز و كيتيناز" و

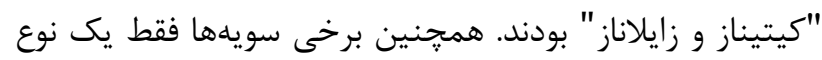
آنزيم را توليد مى كردند بدين صورت كه تعداد درصد سويههاى اندوفيت خالص سازى شده، توليد كننده به ترتيب فقط آنزيم يروتئاز و كيتيناز بودند. هيج يك از باكترىهاى

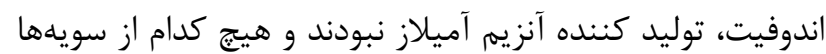
توليد كننده هر سه آنزيم يروتئاز، كيتيناز و زايلاناز نبودند. در

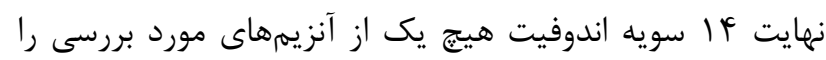
توليد نمى كردند.

از آنجايى كه آنزيم يروتئاز بيشترين توليد را در بين باكترىها

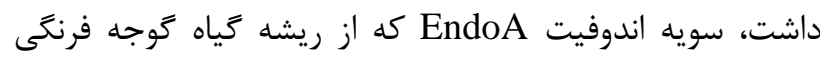
جدا شده بود و بيشترين ميزان توليد آنزيم يروتئاز و همجنين رِّن بيشترين تنوع در توليد آنزيمهاى هيدرولازى مورد بررسى رانئن

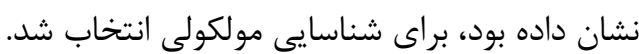
شناسايى مولكولى و تعيين موقعيت فيلوزنى سويههاى اندوفيت

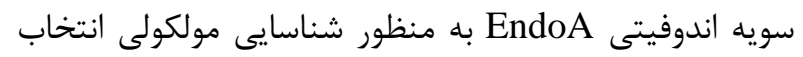

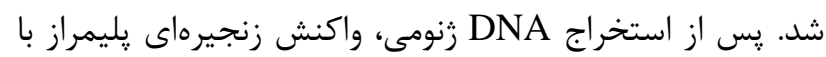
هدف تكثير زن 16S rRNA انجام شد (شكل ؟ند). بعد از توالىيابى، با توجه به آناليز زن 16S rRNA مشخص رن

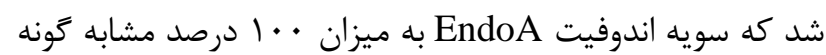
Bacillus halotolerans شماره دسترسى MK817516 ثبت شد. درخت فيلوزنى سويه EndoA

بحث

اندوفيتهاى ميكروبى در تمامى خياهان آوندى حضور دارند. باكترىهاى اندوفيت از ميزبانشان در مقابل عوامل عفونى و وندئ شرايط نامطلوب به وسيله توليد متابوليتهاى ثانويه فعال زيستى،
سانتى گراد به مدت •و ثانيه، دماى اتصال هض درجه سانتى

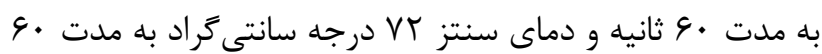

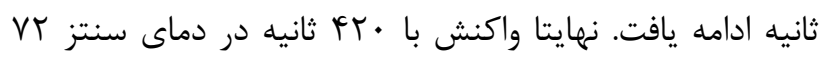
درجه سانتى گراد خاتمه يیدا كرد. محصولات PCR، بوسيله زل الكتروفورز مورد بررسى قرار گرفتند و براى تعيين توالى، نمونهها به شركت ماكروزن در كشور كره جنوبى ارسال شدند.

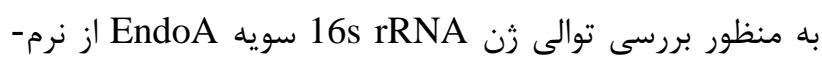
افزار Bioedit استفاده شد. توالى 16S rDNA سويه تونى بونيه EzTaxon-e ساير توالىهاى ثبت شده در يايگاه اطلاعاتى BLAST ،server

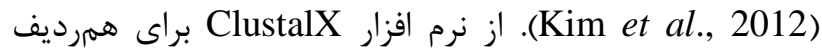
سازى توالىهاى مشابه با EndoA كه از EzTaxon كرفته شده بودند استفاده شد و نرم افزار MEGA6 براى ترسيم درخت فيلوزنى با استفاده از الخوريتم Maximum Likelihood به كرمدئ كار كرفته شد.

\section{نتايج}

\section{بررسى روشهاى جداسازى باكترىهاى اندوفيت}

نمونههاى گياهى با هر سه روش استريل سازى تيمار شده و

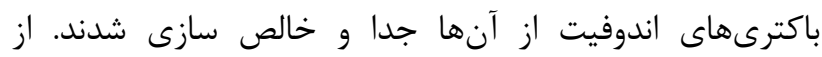

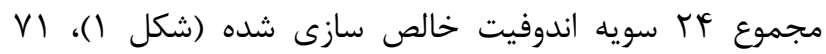
درصد سويهها به كمك روش اول و جr درصد آنها به كمك روش دوم جداسازى شدند. با استفاده از روش سوم هيج سويه اندوفيتى جداسازى نشد (شكل r). كلنى حدود ال

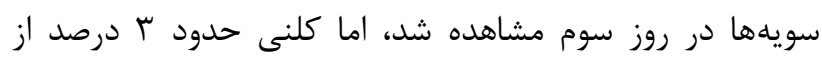

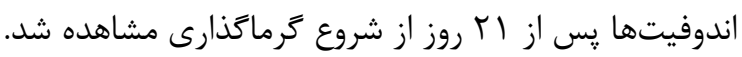
از باكترىهاى اندوفيت خالص سازى شده، سب درصد از سويهها

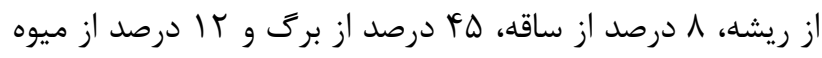
جدا شدند. هيج باكترى اندوفيتى از گل نمونهای ناى زياهى جداسازى نشد (شكل س).

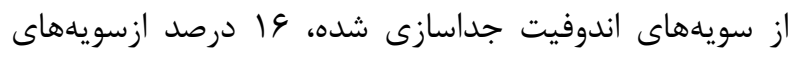

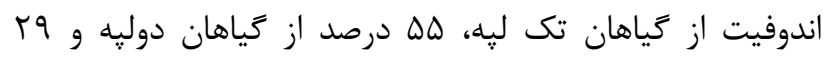

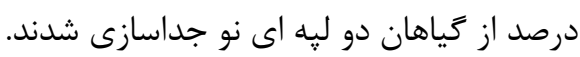
بررسى توانايى توليد آنزيمهاى هيدرولازى دئ دوري

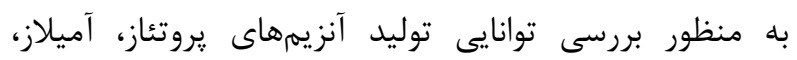
كيتيناز و زايلاناز، باكترىهاى اندوفيت بر روى محيطهاى كشت برون سنجش مربوط به هر آنزيم، كشت داده شدند. نتايج نشان داد كه وله

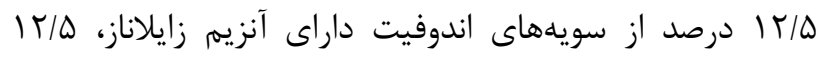
درصد داراى آنزيم كيتيناز و سب درصد از سويهها داراى آنزيم يروتئاز هستند (شكل ؟). 


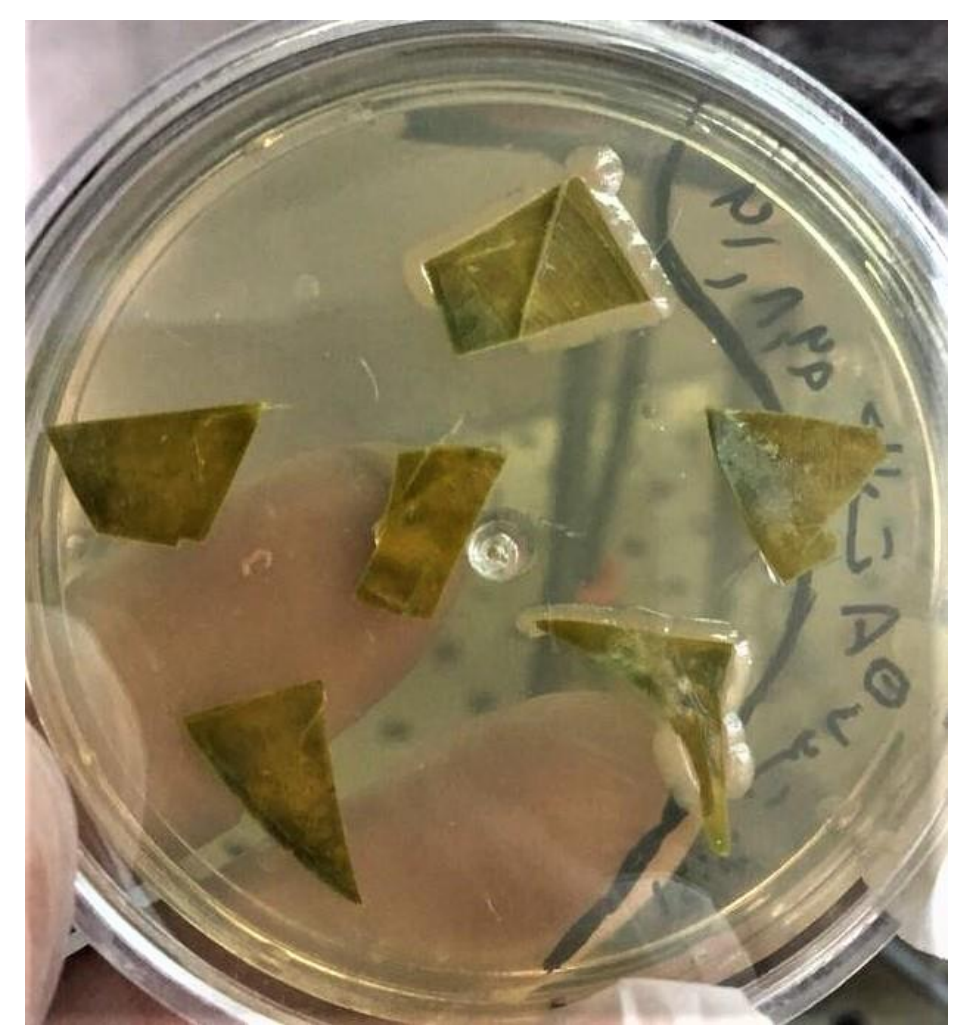

شكل ا- رشد باكترى اندوفيت در اطراف بافت كياهى، استريل شده به روش دوم غربالكرى باكترىهاى اندوفيت.

Fig. 1. Endophyte growth around plant tissue, sterilized by the second method of endophytic bacterial screening.

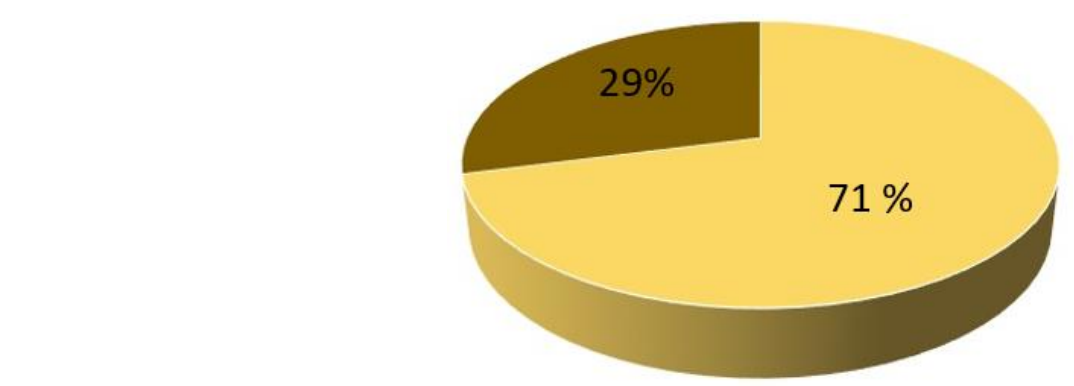

شكل r- مقايسه روشهاى مختلف براى جداسازى باكترىهاى اندوفيت. روش اول ال درصد (رنگ روشن) و روش دوم جr درصد (رنگ تيره)

Fig. 2. Comparison of different methods for isolation of endophytic bacteria. The first method, 71\% (bright color) and the second method, $29 \%$ (dark color).

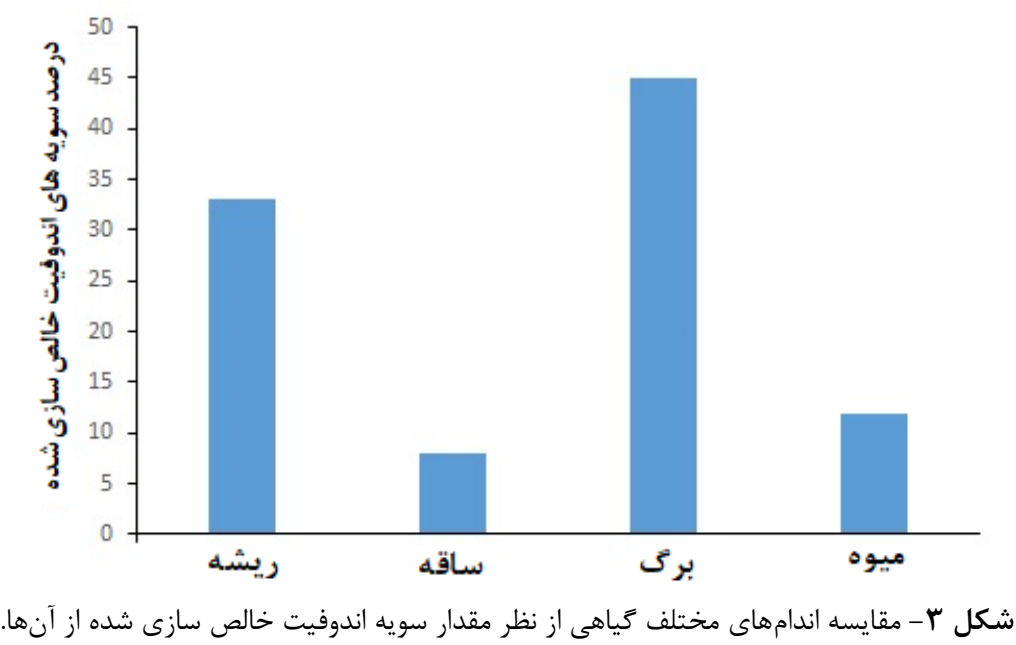

Fig. 3. Comparison of different plant organs in terms of the amount of their purified endophytic strains. 


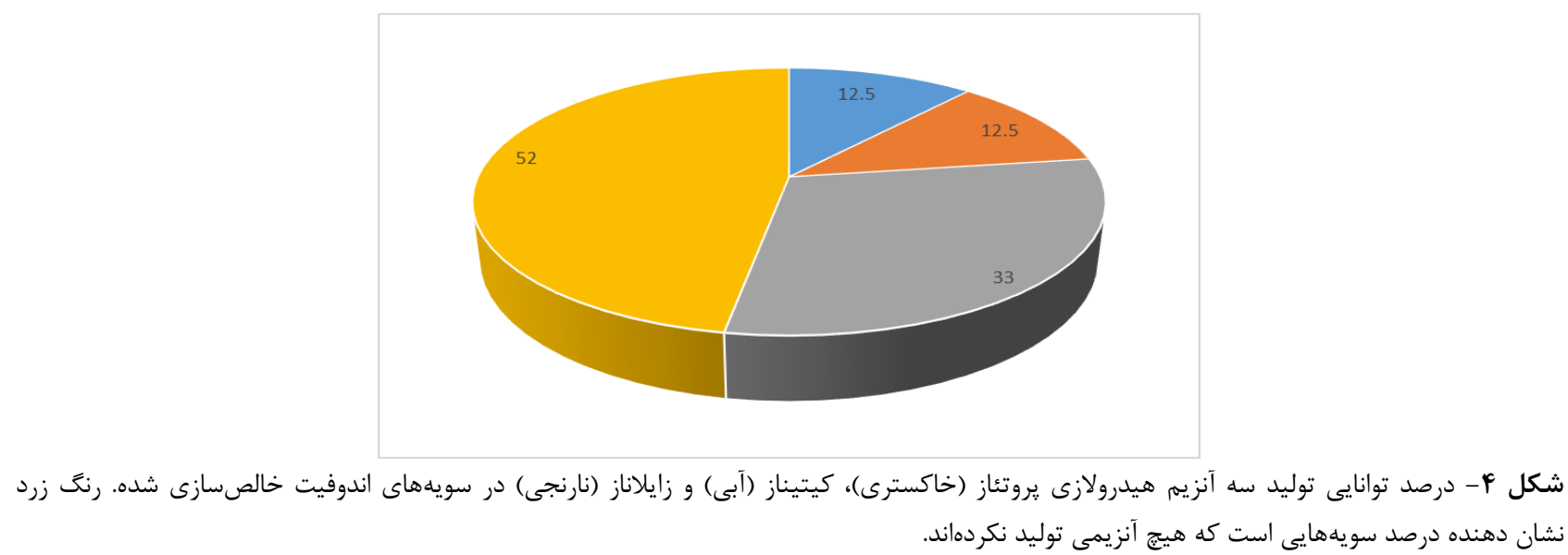

Fig. 4. The ability to produce protease (gray), chitinase (bleu) and xylanase (orang) in purified endophytic strains. Yellow color shows the percentage of strains with no enzyme production.

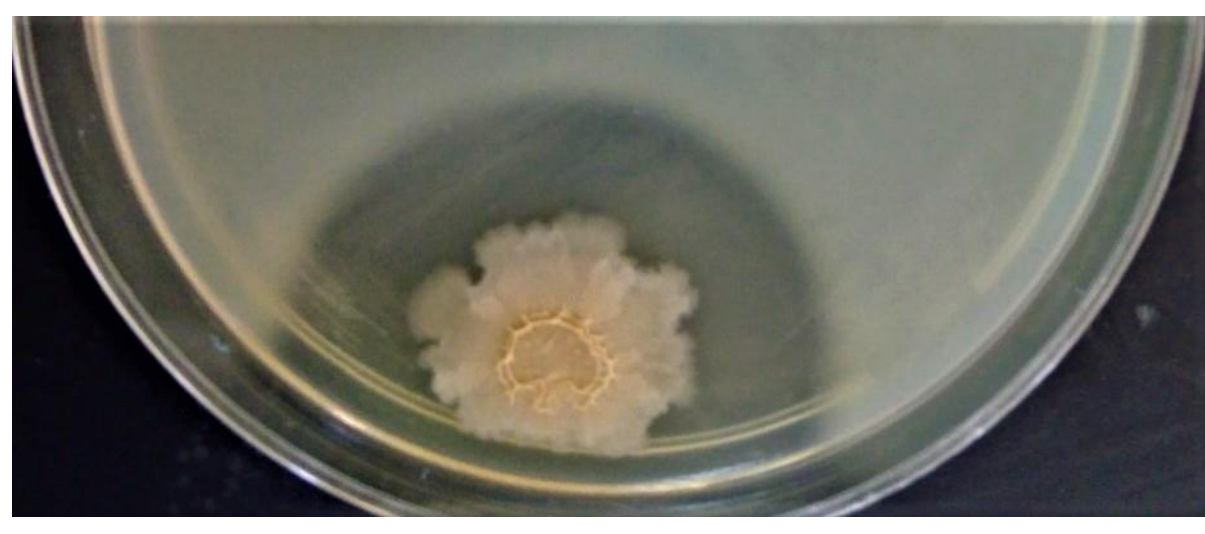

شكل ه- نمونهاى از توليد آنزيم بروتئاز توسط سويههاى اندوفيت

Fig. 5. Protease enzyme produced by endophytic strains.

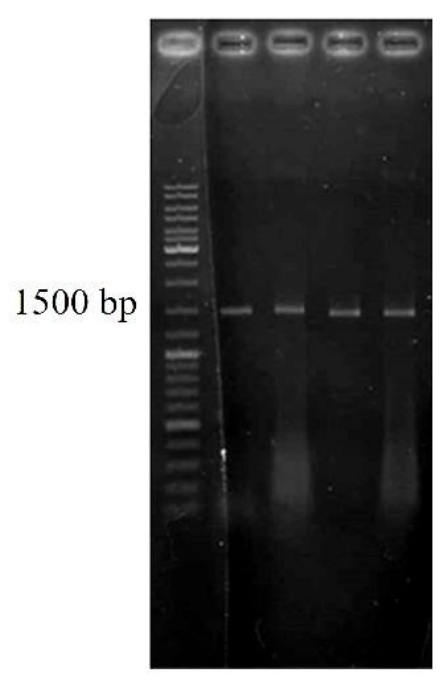

A

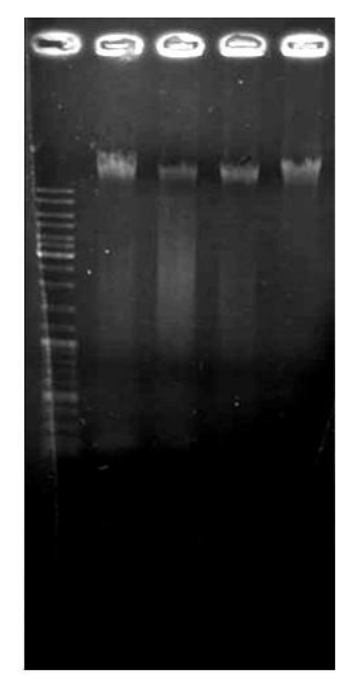

B

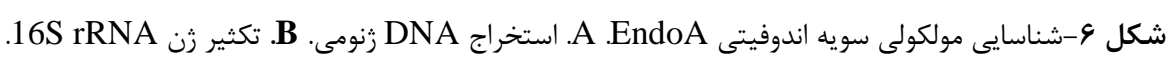

Fig. 6. Molecular identification of endophytic strain EndoA. A. genomic DNA extract. B. proliferation of 16s rRNA gene. 


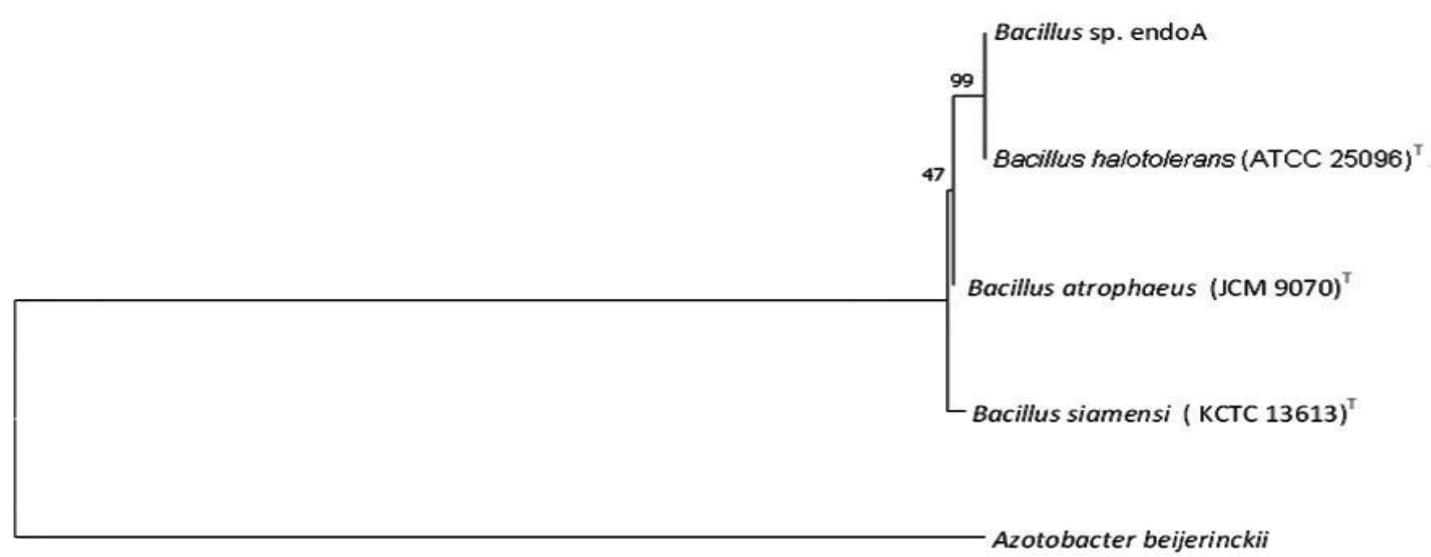

$\longmapsto 0.050$

شكل V- درخت فيلوزنى سويه اندوفيتى Azetobacter beijerinckii .EndoA به عنوان گروه خارجى انتخاب شد. ارزش بوت استرب در محلهاى انشعاب آورده شده است. بار= له درصد فر

Fig. 7. The phylogenetic tree of EndoA endophytic strain and its close relatives. Azotobacter beijerinckii was selected as an outgroup. Bootstrap value is given in the branching region. Bar $=5 \%$.

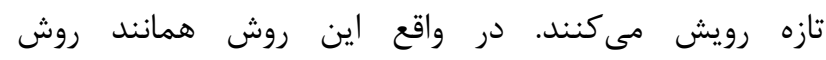

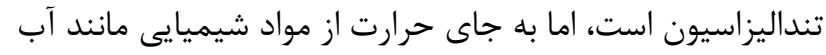

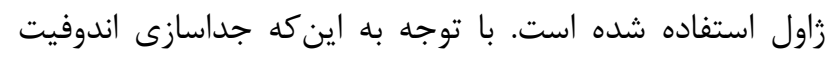
بستخى به حذف كامل باكترىهاى ايىفيت دارد و ايى فيتهاى داراى اندوسيور به سختى از بين مىروند، اين روش توانست در بـ آنسي

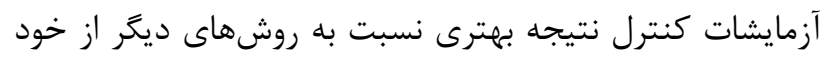

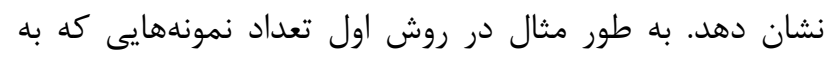
دليل استريل نشدن سطحى بافتها در آزمايش كنترل كنار حذاشته مىشدند، حدود · V درصد بودند. اما در روش دوم تنها • 1 درصد از نمونهها به علت آلودگى كنار كذاشته شدند. بر اساس نتايج به دست آمده، بيشتر سويههاى اندوفيتى از

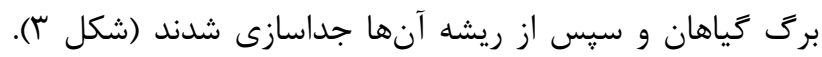
در ززارش ديخرى نيز كه به منظور جداسازى اندوفيتها انجام گرفته است، بيشترين ميزان جداسازى مربوطه به اندام برى دئ

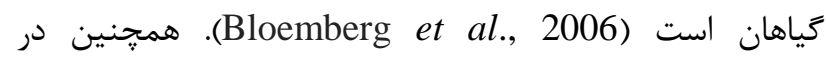
مطالعهاى ديخر بيشترين سويههاى اندوفيتى از ريشه و سيس از ساقه و برى جداسازى شدند (De Almeida Lopes, 2018).

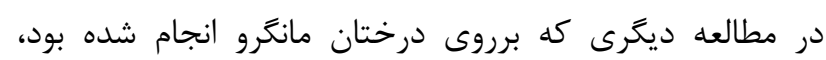

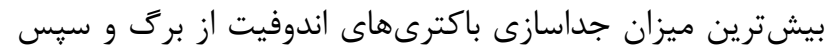

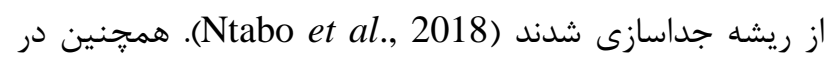
اين تحقيق بيشترين ميزان باكترىهاى اندوفيت از زياهان دوليهاى جداسازى شدند كه اين نتيجه ييش از اين هم مشاهدي

شده بود (Arnold \& Engelbrecht, 2007).
محافظت مى كنند و بنابراين نقش مهمى در زندگى ميزبانشان

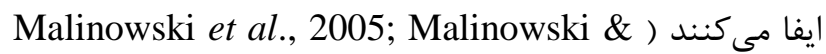
Belesky, 2006; Tintjer \& Rudgers, 2006 وجود اين ميكروار كانيسمهاى هم زيست با كياه ثابت شده اما

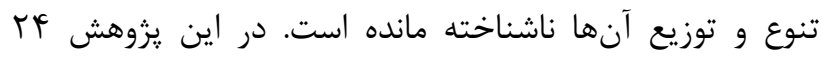

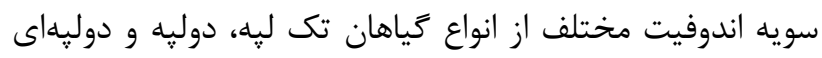
نو جداسازى شدند. براى اين منظور از سه روش جداسازى

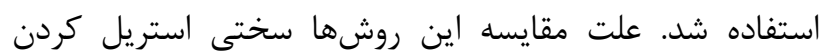
سطح گياه است، زيرا برخى باكترىهاى ايىفيت داراى اسيور درونى بوده و بنابراين نسبت به مواد شيميايى استريل كننده مانند آب زاول مقاوم هستند. همجنين از آنجايى كه رش رشد باكترىهاى اندوفيت به دليل انتقال باكترى از درون زياه به هيه محيط كشت زمان بيشترى به نسبت رشد باكترىهاى سطحى

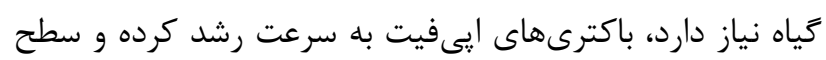
يليت را مىيوشانند و تشخيص ايىفيت از اندوفيت غير ممكن مىشود. در نتيجه يافتن روشى بهينه كه باكترىهاى ايىفيت

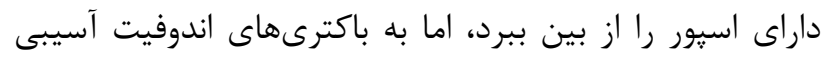

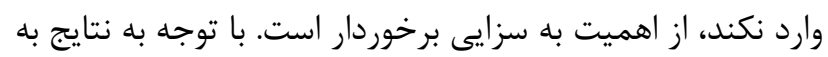

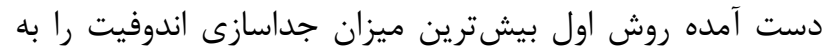
خود اختصاص داد (شكل r). همجنين علت به كارگيرى روش رئن دوم كه طولانى تر از بقيه روشها و ابداعى است و دومين رتبه در جداسازى اندوفيتها را به خود اختصاص داده است، از بين بردن رون اسيورهايى است كه در هر مرحله از مراحل سه گانه اين روش، 


\section{REFERENCES}

Arnold, A.E. and Engelbrecht, B.M.J. 2007. Fungal endophytes nearly double minimum leaf conductance in seedlings of a neotropical tree species. - J. Tropic. Ecol. 23: 369-372.

Bibi, F., Naseer, M.I., Yasir, M., Al-Ghamdi, A.A.K. and Azhar, E.I. 2018. LC-MS based identification of secondary metabolites from marine antagonistic endophytic bacteria. - Genet. Mol. Res. 17: 1-14.

Bloemberg, G.V. and Carvajal M.M.C. 2006. Microbial interactions with plants: a hidden world. In microbial root endophytes. 321-333. Springer, Berlin, Heidelberg.

Carrim, A.J.I., Barbosa, E.C. and Vieira, J.D.G. 2006. Enzymatic activity of endophytic bacterial isolates of Jacaranda decurrens Cham. (Carobinha-do-campo). - Braz. Arch. Biol. Tech. 49: 353-359.

Christina, A., Christapher, V. and Bhore, S.J. 2013. Endophytic bacteria as a source of novel antibiotics: an overview. - Pharmacogn. Rev. 7: 11-16.

Cowan, D.A. 1991. Industrial enzymes. In biotechnology, the science and the business eds moses, V. and cape,

R.E. pp 311-340. Reading: Harwood Academic Publishers.

De Almeida Lopes, K.B., Carpentieri-Pipolo, V., Fira, D., Balatti, P.A., López, S.M.Y., Oro, T.H. and Degrassi, G. 2018. Screening of bacterial endophytes as potential biocontrol agents against soybean diseases. J. App. Microbial. 125: 1466-1481.

Gasser, I., Cardinale, M., Müller, H., Heller, S., Eberl, L., Lindenkamp, N., Kaddor, C., Steinbüchel, A. and Berg, G. 2011. Analysis of the endophytic lifestyle and plant growth promotion of Burkholderia terricola ZR212. - Plant Soil 347: 125-137.

Joshi, S., Singh, A.V. and Prasad, B. 2018. Enzymatic activity and plant growth promoting potential of endophytic bacteria isolated from Ocimum sanctum and Aloe vera. - Int. J. Curr. Microbiol. App. Sci. 7: 2314-2326.

Kim, M., Morrison, M. and Yu, Z., 2011. Evaluation of different partial 16S rRNA gene sequence regions for phylogenetic analysis of microbiomes. - J. Microbiol. Meth. 84: 81-87.

Kim, O.S., Cho, Y.J., Lee, K., Yoon, S.H., Kim, M. and Na, H. 2012. Introducing EzTaxon-e: a prokaryotic $16 \mathrm{~S}$ rRNA gene sequence database with phylotypes that represent uncultured species. - Int. J. Syst. Evol. Micr. 62: 716-721.

Liu, Y., Guo, J., Li, L., Asem, M.D., Zhang, Y., Mohamad, O.A., Salam, N. and Li, W. 2017. Endophytic bacteria associated with endangered plant Ferula sinkiangensis KM Shen in an arid land: diversity and plant growth-promoting traits. - J. Arid Land 9: 432-445.

Lodewyckx, C., Vangronsveld, J., Porteous, F., Moore, E.R., Taghavi, S., Mezgeay, M. and der Lelie, D.V. 2002. Endophytic bacteria and their potential applications. - Cr. Rev. Plant Sci. 21: 583-606.

Malinowski, D.P. and Belesky, D.P. 2006. Ecological importance of Neotyphodium spp. grass endophytes in agroecosystems. - Grassland Sci. 52: 1-14.

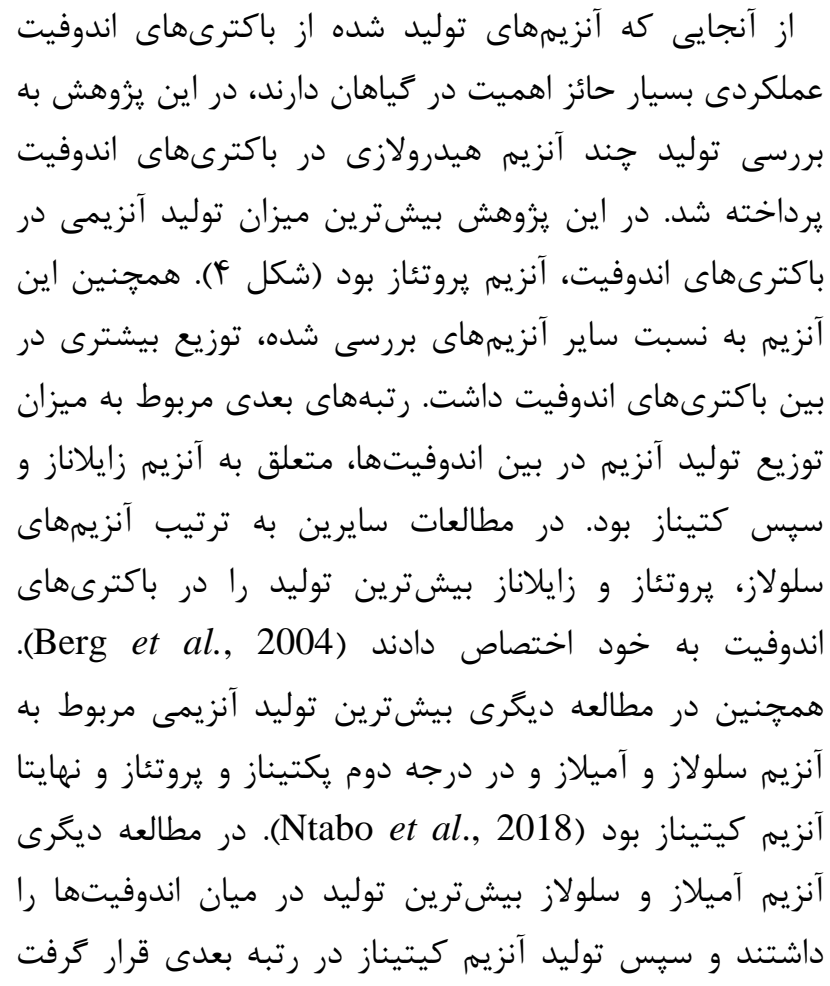

.(Joshi et al., 2018)

$$
\begin{aligned}
& \text { سياسگزارى }
\end{aligned}
$$

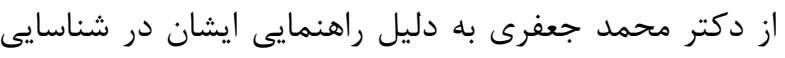

$$
\begin{aligned}
& \text { كياهان تشكر مىنماييه. }
\end{aligned}
$$


Malinowski, D.P., Zuo, H., Belesky, D.P. and Alloush, GA. 2005. Evidence for copper binding by extracellular root exudates of tall fescue but not perennial ryegrass infected with Neotyphodium spp. endophytes. - Plant Soil 267: 1-12.

Marmur, J. 1961. A procedure for the isolation of deoxyribonucleic acid from micro-organisms. - J. Mol. Biol. 3: 208-218.

Ntabo, R.M., Nyamache, A.K., Lwande, W., Kabii, J. and Nonoh, J. 2018. Enzymatic activity of endophytic bacterial isolates from selected mangrove plants in Kenya. - Open Microbiol. J. 12: 354-363.

Reece, J.B., Urry, L.A., Cain, M.L., Wasserman, S.A., Minorsky, P.V. and Jackson, R.B. 2014. Campbell biology (No. s 1309). Boston: Pearson.1263 pp.

Reinhold-Hurek, B. and Hurek, T. 2011. Living inside plants: bacterial endophytes. - Curr .Opin. Plant. Biol. 14: 435-443.
Sánchez-López, A.S., Thijs, S., Beckers, B., GonzálezChávez, M.C., Weyens, N., Carrillo-González, R. and Vangronsveld, J. 2018. Community structure and diversity of endophytic bacteria in seeds of three consecutive generations of Crotalaria pumila growing on metal mine residues. - Plant Soil 422: 51-66.

Taechowisan, T., Peberdy, J.F. and Lumyong, S. 2003. Isolation of endophytic actinomycetes from selected plants and their antifungal activity. - World J. Microbiol. Biotechnol. 19: 381-385.

Tintjer, T. and Rudgers, J.A. 2006. Grass-herbivore interactions altered by strains of a native endophyte. New Phytol. 170: 513-521.

Wejse, P.L. and Ingvorsen, K. 2003. Purification and characterization of two extremely halotolerant xylanase from a novel halophilic bacterium. - Extremophiles 7: 423-431.

How to cite this article:

Khosroshahi, S., Salehghamari, E., Amoozegar, M.A. and Saffarian, P. 2020. Screening methods and enzyme profile of agricultural plant endophytic bacteria. - Nova Biolo. Reperta 6: 415-423. (In Persian)

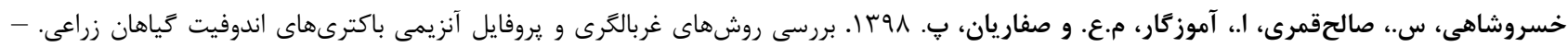

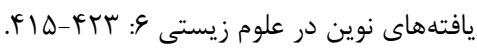

